\title{
MULHER JOVEM E CIBERCULTURA: LIBERDADE, SUBORDINAÇÃO E REMINISCÊNCIAS PATRIARCAIS NO MEIO VIRTUAL ${ }^{1}$

\section{Resumo}

O presente artigo versa sobre a exposição de imagens femininas e de suas múltiplas formas de exploração, fetichização e espetacularização em contextos de ampla divulgação e circulação através da cibercultura. Toma-se como recurso a revisão historiográfica, mas especialmente a construção de ambientes virtuais de grande exposição imagética feminina, podendo constituir violência e crime. Deste modo, o objetivo é abordar as representações de mulheres corpos e sexualidades - no ciberespaço, perpassando temas como cibercultura, culturas juvenis, dominação masculina e violência contra a mulher, marcos legais específicos e ciberfeminismos.

Palavras-chave: cibercultura, violência contra a mulher, ciberfeminismo, objetificação do corpo

\begin{abstract}
Young woman and cyberculture: freedom, subordination and patriarchal reminiscences in the virtual environment

The present work is about the exposure of female images and their multiple ways of exploitation, fetishization and spectacularization in a context of huge disclosure and circulation though the cyberculture. The resource is historiographic review, especially construction of virtual environments of great exposure of female imagery, which can configure violence and crime. The aim is to address women's representations - body and sexuality - in the cyberspace through themes such as cyberculture, young culture, male domination and violence against women, specific legal rights frameworks and cyberfeminism.
\end{abstract} the body

Keywords: cyberculture, violence against women, cyberfeminism, objectification of

Resumen

Mujer joven y cibercultura: libertad, subordinación y reminiscencias patriarcales en el medio virtual

En este artículo se trata de la exposición de imágenes del sexo femenino y sus múltiples formas de explotación, fetichismo y espectáculo en contextos de amplia difusión y

Núcleo de Estudos sobre Direitos Humanos. Programa de Pós-Graduação em Família na Sociedade Contemporânea, Universidade Católica do Salvador, Bahia, CEP: 40231-902, Brasil.

Endereço eletrónico: mariana.riserio@hotmail.com

Endereço Postal: Av. Cardeal da Silva, 205 - Federação - Salvador, Bahia, Brasil, CEP 40231-902.

** Núcleo de Estudos sobre Direitos Humanos. Programa de Pós-Graduação em Família na Sociedade Contemporânea, Universidade Católica do Salvador, Bahia, CEP: 40231-902, Brasil.

Endereço eletrónico: vanessa.cavalcanti@uol.com.br

Agradecimentos: A Dra Mary Garcia Castro (Universidade Católica do Salvador) e Daniela Serra Castilhos (Universidade Portucalense, Portugal) pelas sugestões e recepção de estágio de mobilidade internacional no segundo caso. 
circulación a través de la cibercultura. Toma como recurso la revisión historiográfica, pero sobre todo la construcción de entornos virtuales de gran exposición de la imagen femenina que puede constituir violencia y crimen. Por lo tanto, el objetivo es abordar las representaciones de las mujeres - cuerpo y sexualidad - en el ciberespacio, a través de temas tales como cibercultura, culturas juveniles, dominación masculina y violencia contra las mujeres, ciberfeminismos y marcos legales específicos. objeto

Palabras clave: cibercultura, la violencia contra la mujer, ciberfeminismo, cuerpo

As CiberFeministas eram pensadoras tecno-utópicas, que viam a tecnologia como uma maneira de dissolver as divisões de sexo e gênero. Certamente elas sabiam que o mundo digital e as culturas que dele emergiam, especulativas ou outras, continham tanta dinâmica de poder nas relações quanto o mundo real; o termo «CiberFeminismo» é em parte uma crítica às implicações misóginas da literatura ciberpunk da década de 1980. No entanto, as CiberFeministas acreditavam na Internet como uma ferramenta para a liberação feminista. ${ }^{2}$ (Evans 2014)

\section{Introdução}

Em tempos virtuais e de intensificação das relações digitais, há que se fazer uma advertência dialética sobre o tema em apreço. O presente artigo toma como lócus de análise a cibercultura, entendida como a cultura engendrada no ciberespaço, fundada em uma nova forma de comunicação criada pela interconexão de computadores (Lévy 2009). Dentro deste contexto maior, nos debruçamos sobre os ciberfeminismos (movimentos feministas iniciados na década de 1980) propagando observações sobre as relações estabelecidas entre as mulheres e a Internet, sejam as relações profissionais, acesso e informação, as violências sofridas e os enfrentamentos utilizando os instrumentos que a Internet proporciona (diversidade de usuários, simultaneidade, atemporalidade e largo alcance) (Lemos 2009). Em contrapartida, o trabalho expõe uma prática de violência contra a mulher que se desenvolve na rede, contra jovens brasileiras, onde a exposição imagética multimeios e sua amplidão ofende/constrange/intimida as mulheres e os ciberfeminismos se propõem a agir em sua erradicação. Neste âmbito, situamos dois casos ocorridos no Brasil para ilustrar as violações na contemporaneidade.

As violências de gênero tomam diversas formas e efeitos, sendo os impactos morais tão devastadores ou mais do que os que deixam marcas físicas. Há cinco

Tradução livre das autoras. Original: «The CyberFeminists were techno-utopian thinkers who saw technology as a way to dissolve sex and gender divisions. Of course, they knew that the digital world, and the cultures emerging from it, speculative and otherwise, contained as many gendered power dynamics as the real world; the term «CyberFeminist» itself is partially a critique of the misogynistic overtones of cyberpunk literature in the 80s. Still, the CyberFeminists believed in the Internet as a tool of feminist liberation». 
décadas tomaram forma movimentos direcionados a reflexão, valorização, busca da igualdade e denunciação das inúmeras formas de discriminações sofridas pelas mulheres. Apesar das agendas, tanto nacional quanto internacionalmente, os marcos legais e a categorização do desrespeito à integridade como violação aos Direitos Humanos, violências existem e resistem, em diversas expressões, contextos e novos espaços.

Há na Internet uma ampla divulgação imagética pessoal que abrange todos os momentos das vidas das pessoas comuns. Ligados a este fenômeno estão a cultura do espetáculo, a mercantilização da vida e a busca da fama como categorias específicas do sistema de reprodução social. Neste contexto, de identificação de sujeitos em sua forma jurídica e contratual, surgem novas formas de relacionamento entre jovens - através do envio de imagens íntimas por redes sociais, comunicadores instantâneos etc. - com a finalidade de ampliar virtualidades e realidades. Vem à tona a persistência - para além de um direito individual - da configuração patriarcal como representação redutora de uma modernização estabelecida e garantida com as esferas econômicas e políticas da própria riqueza abstrata quando as imagens de mulheres são mais divulgadas, repercutidas e ridicularizadas no papel/ lugar de objeto de desejo sexual de outrem.

Busca-se discutir os desenhos que se conformam em um tempo em que a autoexpressão das mulheres, sua emancipação e transcendência lutam com tradicionalismos e ranços patriarcais. Não obstante a dialética da vontade geral, tomam forma os movimentos contra-hegemônicos e «ciberfeministas» reivindicando que o lugar da mulher deve ser onde ela quiser (Natansohn 2013); sem romper com o absolutismo da forma mercadoria e a salvaguarda metaestatal no espaço do mercado mundial que, parafraseando Robert Kurz (2011), engendram a valorização do valor como o sujeito automático da sociedade.

\section{Caminhos cibernéticos e novas ciberculturas}

A Internet ocupa de forma intensa a dualidade do cotidiano, a dialética da liberdade dos que têm acesso ao meio, enfatizando os contornos da globalização, permitindo ao usuário uma sensação de acesso a qualquer cultura (Castells 2003). Em um ínfimo período de tempo, alcançou em número de usuários o que outros meios revolucionários - no sentido de progresso tecnológico, científico e econômico; não emancipatório - demoraram incomparavelmente mais (Dornelles 2004).

Seja para resoluções financeiras, programações de detalhes de viagens, compras de toda ordem, entretenimento (jogos, filmes, multimeios etc.), é impensável a ausência desta ferramenta na contemporaneidade (Castells 2003). Além da falaciosa oferta de liberdade, um fenômeno específico da Modernidade, oferece externamente ao indivíduo a possibilidade de ser criador neste simulacro da universalidade abstrata na forma mercadoria. Essa característica não se restringe ao processo criador, abrangendo também a alegoria do software livre, onde programadores têm 
acesso a como se deu sua criação, podendo repeti-la ou modificá-la (Castells 2003), mas também se tratando de subjetividades.

Como escreveu Paula Sibilia (2008), em La intimidad como espetáculo, a Internet abre o espaço para a pessoa se mostrar/criar da forma que melhor atender às suas expectativas (podendo elas estarem ligadas aos estereótipos sociais). As autobiografias são uma curiosa representação dessa inserção criadora em forma de simulacro (entendida como uma lógica própria, independente da lógica universal do valor, que não consegue romper com os grilhões da riqueza abstrata e da forma jurídica), pois apresenta uma linguagem atualizada da «novilíngua» orwelliana: a valorização das pessoas comuns face a vida enaltecida de celebridades entendida como uma mais-valia da banalização e ampla divulgação da mediocridade em uma sociedade em que o «aparentar ter» está a suplantar o «ser».

Pode-se inferir que a apreciação de formas de vida, expressões estereotipadas socialmente, tem levado as pessoas (o que já ocorre há muito tempo) a busca de fama e lugar na mídia como forma delas mesmas representarem o que elas admiram, tenha esta necessidade relevo social ou não. Essas considerações corroboram as proposições críticas de Bauman (2008), em Vida para Consumo, ao descrever situações em que pessoas buscam como projeto de vida a fama, estando ela relacionada a talentos ou (principalmente) não. A Internet amplia este cenário de forma significativa, dado a condição dos usuários do meio poderem ser autores de suas obras e divulgá-las na rede, ou mesmo de suas próprias vidas em simulacro (Sibilia 2008).

Com essas informações em mente, salta aos olhos que tudo o que ocorre nas vidas comuns é exposto, dos momentos comemorativos aos mais banais, tudo é enaltecido e a fama pode advir da repercussão das «postagens» (likes) entendidas conforme a assertiva debordiana sobre a noção de que tudo o que é vivido deve ser divulgado e só é relevante aquilo que é divulgado, ou seja, a realidade das pessoas se distancia em projeções que as afastam delas mesmas (Debord 1997). Ocorrem, portanto, associações pessoas-produto, mercantilização da vida, valorização do fugaz, fetichização das relações (Lipovetsky 2005; Bauman 2008, 2014; Cavalcanti e Silva 2011), confusões entre esferas público-privado, etc.

Neste contexto, vem à luz o costume atual de momentos íntimos serem divulgados na Internet, concernentes a trocas de imagens sexuais ou de nudez entre jovens como contornos de uma nova forma de se relacionar, em que o sujeito histórico (portanto, político) cede espaço para o recrudescer do sujeito consumidor.

Novos termos surgem com as novas subjetividades: o sexting já possui definição em dicionário ${ }^{3}$ e representa a troca de mensagens com teor sexual podendo conter imagens, as nudes representam o envio de fotografias de nudez e o revenge porn ${ }^{4}$ representa um viés criminoso deste fenômeno, que recai sobre mulheres (majoritariamente), onde homens enviam material sexual ou imagens de nudez

\footnotetext{
3 Definição de sexting no dicionário Macmillan: http://www.macmillandictionary.com/dictionary/ british/sexting. Acesso em 10.11.2016.

Ou «pornô de vingança».
} 
para expor e ridicularizar mulheres com quem se relacionaram, como retaliação face ao término do relacionamento.

A Internet, entendida como uma tecnologia social de/para valorização, desponta como um espaço aberto para expressão de sexualidades, tanto para debates e (re)conhecimento a respeito do tema (essencial na formação do indivíduo), bem como em um processo de tentativa e erro, de exposições em busca de autoconhecimento e êxtase em vivenciar um prazer fugaz sem a mensuração das consequências sociais e políticas advindas (considerando que as velhas formas de consciência e estruturas de poder - sem olvidar da conquista de cidadania - não mais condizem com as novas condições capitalistas de identificação do ser humano com a sua participação no processo de produção e consumo). $\mathrm{O}$ viés de gênero deve ser considerado ao se debruçar sobre o tema que ratifica a sexualização e a objetificação da mulher, fazendo transparecer a cultura patriarcal ainda vigente na sociedade (Saffioti 2004) que à luz da teoria de dissociação-valor (Scholz 2010) é condição sine qua non para compreensão do fetiche e da lógica de reprodução social determinante e contraditória do capital.

\section{Mulheres na Internet: corpos, sexualidades e dominações}

Assim como nas bancas/quiosques de revistas e jornais, a imagem de mulheres nos parâmetros estéticos sociais é amplamente divulgada nas redes digitais. Ligada a expressão visual da cibercultura, se pode citar as musas fitness, ${ }^{5}$ mulheres que exibem modelos alimentares em blogs, mas sobretudo seus corpos, com um contorno de formadoras de opinião sobre uma vida saudável, o que é amplamente controvertido. Junto a elas, corpos seminus que almejam aprovação povoam as redes sociais. Serão eles reflexo de uma libertação sexual bem-sucedida? Por que as imagens sexuais/de nudez divulgadas sem consentimento das mulheres são acompanhadas de um pejo negativo, desmerecedor da mulher casta que ainda povoa o imaginário social? Quais são as fronteiras e consensos (no âmbito inclusive do marco legal-institucional) permitidos?

Giddens (1993), ao abordar as transformações no âmbito da intimidade e dos relacionamentos, refere que, da passagem do amor romântico (que subjugava as mulheres mais explicitamente), ao relacionamento puro, que seria baseado em diálogos e realização de ambas as partes, houve a reivindicação da mulher por maior expressão, autonomia e emancipação por um tratamento igualitário, física e emocionalmente.

No entanto, trata-se de um processo em curso no qual as mulheres são como «cobaias» sociais e, tanto como os homens, ainda estão assimilando as mudanças.

«Você segue uma musa fitness? Isso pode fazer mal a sua saúde». In: Veja.com, 8.8.2016. Disponível em http://veja.abril.com.br/saude/voce-segue-uma-musa-fitness-isso-pode-fazer-mal-a-suasaude/. Acesso em 10.11.2016. 
Os homens, submetidos deste modo (em maior ou menor medida) ao estigma de virilidade e dominação, somente podem responder de forma violenta às investidas da emancipação feminina (Giddens 1993).

Na reminiscência de um comportamento dominador, namorados controlam chamadas telefônicas, mensagens de texto e, mais recentemente, utilizam a posse de imagens íntimas como moeda de troca de chantagens emocionais (Plou 2013). Este fato demonstra não só a resistência do poder masculino, como a insistente sexualização do corpo feminino, uma vez que imagens de homens possuem uma repercussão ínfima em suas «reputações» em face de imagens de mulheres.

Numa época em que a libertação sexual possui lugar e contextos específicos, cabe a consideração abaixo:

São tempos que se embaralham entre a nudez e as burcas; a virgindade vendida e as genitálias expostas; o silêncio e a violência; o hedonismo e a anedonia. Mostrar ou não mostrar, essa é a proposta das sociedades ocidentais, sob a égide do espetáculo. $\mathrm{O}$ cobrir e o descobrir, o velar e o revelar. Mas o que existe, de fato, entre tais contrastes? São os dois lados da intolerância, do pudor, da pornografia? Volto, com essas interpelações, à pergunta: de quem é o corpo afinal? (Santos 2014, 119).

Conforme Heleieth Saffioti (2004), as mulheres foram socializadas em uma ordem patriarcal de gênero, que representa, além de uma ideologia, uma estrutura de poder em detrimento das mulheres. Tal ordem, conduzida por preceitos que as depreciam e inferiorizam, as conduz a um comportamento dócil, casto, cordato, sendo o contraponto masculino, e sua característica, a agressividade, a ideia de sobreposição e posse em relação ao corpo feminino, que, quando não age conforme os seus desígnios, pode sofrer violentas retaliações. Frise-se que «um dos elementos nucleares do patriarcado reside exatamente no controle da sexualidade feminina, a fim de assegurar a fidelidade da esposa a seu marido» (Saffioti 2004, 49). Fato muito pertinente para se trabalhar o revenge porn.

Saffioti (2004) refere que algumas feministas defendem que o conceito de patriarcado representaria um momento passado na história, enquanto agora haveria apenas resquícios de um período em que realmente houve a primazia masculina. Defende que, assim como demais fenômenos histórico-sociais, o patriarcado está em transformação, não deixando de existir na atualidade, o que se põe visível nos índices de violências e atrocidades contra as mulheres praticadas em todo o mundo e a todo o tempo. Nesta lógica sexista, as próprias mulheres podem reproduzir o comportamento e o imaginário machista, não questionando o lugar de inferioridade que lhes puseram (Saffioti 2004).

O que é interessante e vale a pena trazer para a presente discussão é que em um ambiente de ondas reacionárias, as mulheres conscientes do lugar que ainda as querem colocar, buscam, em um movimento tentativa-erro, se expressar da forma que lhes convém, ou seja, ainda que sofrendo repressões e violências, procuram concretizar anseios e expressões em busca da sua liberdade. 
Violações de ordem estética, de ordem física e moral, sejam percebidas por quem as sofre ou não, permeiam e constituem a identidade da mulher enquanto esta é afastada de si mesma, do seu real desejo. Há um longo caminho de denúncias e empoderamento onde também a Internet, com o seu poder de conglomeração positiva, pode ser um trilho virtual feminista, como irá se tratar adiante.

\section{Entre subordinação e liberdade: os ciberfeminismos}

As violências contra as mulheres propagadas na Internet têm tido ampla repercussão. Face a isto, as mulheres têm-se organizado em movimentos contra-hegemônicos para enfrentar a violência no próprio meio em que ela é propagada. Em campanhas, exposições de fotografias de corpos «reais», organizações para incentivar o acesso e também o trabalho das mulheres na área das tecnologias, criações de aplicativos, entre outros exemplos, são várias as vertentes e vozes emergentes na cibercultura.

Dentro dos movimentos sociais das décadas de 1960 e 1970, o analógico definia-se como forma e instrumento. Contudo, a partir da década de 1980, o ciberfeminismo ocupa palco e agendas, especialmente tendo como obra fundamental e inspiradora O Manifesto Ciborgue, de Donna Haraway, publicado em 1987 e distribuído nos anos seguintes como referência. $\mathrm{O}$ eixo temático proposto por esse trabalho foi que as mulheres entrariam em nova fase identitária, reforçada e alicerçada pelas tecnologias. Da ficção às artes, das ciências aos processos estéti$\cos$, a identidade seria definida como ciborgue (uma mescla entre as acepções de cibernética e organismo) (Haraway 2009).

«Em fins do século XX - nossa era, um tempo mítico - todos somos quimeras, híbridos teorizados e fabricados de máquina e organismo; em uma palavra, somos Ciborgues. O Ciborgue é nossa ontologia, nos outorga nossa política» (Haraway 2009, 57). A partir dessa assertiva e argumento, a mudança para uma figura ciborgue se construiria em oposição radical à ideia de «deusa», de mulher-mito e mitológica, caracterizada por nuances tradicionais e de elaboração-ocupação de papéis. Havia já componentes de crítica ao patriarcado e ao processo violento e desigual vivenciado pelas mulheres.

Conforme Lemos (2009), o ciberfeminismo remonta à década de 1990 e no seu início configurou-se para discutir as relações profissionais entre mulheres e tecnologias, inserção feminina no meio e estabelecimento de uma rede de comunicação entre as mulheres. Relaciona-se com a construção de novas ordens, desconstrução de velhos mitos da sociedade através do uso da tecnologia, engendrando e refletindo sobre novas subjetividades.

Tendo-se em vista que na Internet os usuários são ao mesmo tempo receptores e emissores da mensagem (Lévy 2009), abre-se um espaço multifacetado para a dimensão ciberfeminista que se expressa adequada às características da Internet, abrangendo de forma simultânea uma gama de ativistas que poderiam não estar 
presentes fisicamente. Desta forma, são criadas ideias e ações, que vão do virtual ao real colaborando para a amplificação dos ideais de igualdade dentro e fora da rede.

Neste contexto de recepção e emissão, no contexto brasileiro, vale mencionar «Blogueiras Feministas», ${ }^{6}$ blog cuja produção se debruça sobre assuntos cruciais a respeito de mulheres, para informar e conglomerar, tais como aborto, Lei Maria da Penha, Marcha das Vadias, mulheres indígenas, lésbicas, negras, trans, apresentando uma secção de educação e ajuda com a exposição de ouvidorias, assistência jurídica e textos instrutivos em caso de violências.

Transpondo-se ao «real», se configura o «meninas digitais», ${ }^{7}$ projeto que tem realização na Secretaria Regional de Mato Grosso da Sociedade Brasileira de Computação (SBC) em 2011 e, em 2015, foi institucionalizado pela SBC como programa de interesse nacional da comunidade e existe sob coordenação do Prof. Dr. Cristiano Maciel (Secretário Regional da SBC de Mato Grosso; professor da UFMT), desde maio de 2011, e da Prof. a Dra. Sílvia Amélia Bim (Secretária Adjunta da SBC do Paraná, professora da UTFPR), desde julho de 2012.

No intuito de levar a área da informação e das tecnologias da informação e comunicação ao ensino médio e finais do ensino fundamental, já tem grande proporção em território nacional (Brasil), se alastrando em ações e oficinas por Belo Horizonte, Natal, Cuiabá, Curitiba e Maceió. Esse trabalho ganha relevo no presente, uma vez que o discurso amplifica o seu poder quando transformado em ação e, em um contexto onde a relação entre mulheres e tecnologias apresenta grandes insuficiências, levar meninas ao contato acadêmico e profissional com a área representa um potencial transformador. Por outro lado, no Brasil, os blogs alcançaram um vasto impacto social, em que os movimentos contra-hegemônicos dinamizaram e amplificaram suas vozes. Os blogs que se propõem a tratar temas de interesses das mulheres desenvolveram uma rede de ajuda significativa para o empoderamento feminino, divulgando informações e incutindo coragem para suas leitoras.

A área das tecnologias de informação é diversas vezes negligenciada para as meninas e mulheres, sendo estereotipadamente relacionada a homens, motivo pelo qual o projeto «meninas digitais» se desponta socialmente com grande relevo. Neste fluxo, o ano 2015 floresceu no Brasil em campanhas lançadas na rede que obtiveram uma ampla repercussão na rede e, possivelmente, para fora dela, adentrando o «mundo real». A página Olga $a^{8}$ se destacou brilhantemente neste contexto, sendo um projeto autodenominado feminista, criado em 2013, pela jornalista Juliana de Faria. A página reúne um conteúdo sobre as mulheres, suas atividades, denúncias, reflexões sobre passado, presente, futuro e empoderamento, lançando campanhas e projetos que vão do virtual para o real.

http://blogueirasfeministas.com/. Acesso em 16.02.2017.

Webpage «meninas digitais»: https://sbcmt.wordpress.com/meninasdigitais/. Acesso em 20.11.1016. http://thinkolga.com/. Acesso em 31.10.2016. 
Uma campanha que obteve grande repercussão nacional, foi engendrada no contexto em que Juliana de Faria fez uma palestra sobre uma outra campanha da sua página sobre assédio nas ruas. ${ }^{9}$ Faria relatou pela primeira vez em público um assédio sofrido por ela quando era criança e, no misto de sentimentos que envolve esse desabafo, foi questionada sobre a veracidade do seu depoimento (mais um fato para elucidar a culpabilização da vítima).

Neste meio tempo, surgiram comentários sexuais na Internet sobre uma menina de 12 anos, participante do programa de tv/reality show Master Chef, ${ }^{10}$ e a Olga teve a ideia de lançar uma campanha (\#meuprimeiroassédio), no intuito de expor, discutir, refletir e empoderar as mulheres sobre o tema. Tal fato ocorreu em outubro de 2015 e houve a repercussão inesperada de mais de 82000 tweets $^{11}$ sobre o assunto e, diante da análise feita pela Olga em 3111 histórias, observou-se que a idade média do primeiro assédio era de 9,7 anos.

Diante da repercussão, houve a adesão de órgãos como o portal do Governo Federal e a Unicef, que aproveitaram a pauta para reforçar suas próprias campanhas. ${ }^{12}$ Quando se pensa seriamente na necessidade de reeducação e conscientização social, para além da criação de marcos legais específicos, a movimentação das mulheres na Internet (meio que não é posse de grupos específicos) surge com grande potência, movimentando e engajando as pessoas politicamente, tirando-as da zona de conforto.

\section{Tempos virtuais e marcos legais}

Não obstante a normatização legal ter extrema importância, inclusive simbólica, para as violências e violações, a existência de leis não é uma condição definitiva para a erradicação dos crimes. Há, no Brasil, leis específicas para a violência contra a mulher e, apesar deste advento, o imaginário social dando suporte à reminiscência patriarcal não exime a mulher das violências sofridas diariamente.

Outrossim, há que se ressaltar a dificuldade de controle das novas tecnologias. A Internet foi criada em uma promessa de liberdade de acesso, conhecimento e expressão. Sua arquitetura, ao passo que permite anonimato e criação, suprime controle e privacidade. Apesar da devassa das informações praticada por Estados, o cidadão comum se vê sem meios de enfrentar um abuso sofrido na Internet (Castells 2003; Leonardi 2011).

$9 \quad$ Chega de Fiu Fiu http://thinkolga.com/cartilha/. Acesso em 31.10.2016.

10 Matéria Carta Capital http://www.cartacapital.com.br/sociedade/o-masterchef-junior-e-a-sexualizacao-infantil-9362.html. Acesso em 31.10.2016.

11 Matéria em Olga, disponível em http://thinkolga.com/2015/10/26/hashtag-transformacao-82-miltweets-sobre-o-primeiroassedio/. Acesso em 31.10.2016.

12 Matéria no El País, 23.10.2015. Disponível em http://brasil.elpais.com/brasil/2015/10/22/politica/1445529917_555272.html. Acesso em 31.10.2016. 
Não há legislação específica no Brasil face à exibição que ocorre por vingança em relação ao término do relacionamento ou por mero desejo de exibição sem consentimento da pessoa retratada, o que constitui crime. Existem apenas projetos de leis, ${ }^{13}$ sendo eles «possíveis», mas não completamente abrangentes. Não atingimos o patamar de consenso e elaboração de leis que deem proteção e suporte às vítimas dessa violação de intimidade.

No início, a prática da exposição fotográfica sensual e de nudez representava uma tentativa de expressão de liberdade, ainda que controversa, uma vez que autoridades e estudiosos temiam possíveis ocorrências de pornografia infantil. ${ }^{14} \mathrm{O}$ viés da espontaneidade ainda existe em diversos casos (e há várias campanhas de educação e prevenção voltadas a isso), mas, com o passar do tempo e avançar do fenômeno, este passou a ser direcionado enfaticamente a mulheres e não mais por exposição espontânea, mas de terceiros.

\section{Casos}

Os dois casos trazidos aqui para análise refletem o prejuízo para a vítima da ausência de leis eficazes e da perpetuação de um imaginário coletivo machista e opressor, mantendo o corpo feminino nas esferas da sexualização e objetificação.

Caso 1: A jovem Thamiris Sato, à época com 21 anos e estudante na Universidade de São Paulo, teve fotografias divulgadas pelo ex-namorado, Kristian Krastanov, de 26 anos e também estudante na mesma instituição. Thamiris terminou o relacionamento de um ano e sete meses e o rapaz, inconformado, após perseguições e chantagens, a ameaçou de morte em setembro de 2013. Em outubro, a jovem fez um Boletim de Ocorrência face à ameaça e, então, Kristian vazou fotos suas na rede.

A jovem descobriu sobre a circulação em sites pornográficos e perfis falsos no Facebook, após receber mensagens de desconhecidos nesta rede social oferecendo ajuda em troca de favores sexuais. Face ao ocorrido, Thamiris cogitou transferir o curso para outro Estado, fazer intercâmbio e mesmo acabar com a própria vida. Ao falar sobre a hipótese do suicídio, ela disse que o que transformou seu pensamento foi o amor a sua família, ter a noção do sofrimento que este ato ia trazer a eles.

Em resposta à atitude do rapaz, a jovem divulgou um desabafo «Meu desabafo como vítima de revenge porn», contando toda a situação no Facebook, expondo

13 Existem os projetos de Lei: PL n. ${ }^{\circ}$ 5.555/2013; PL n. ${ }^{\circ}$ 5822/2013; PL n. ${ }^{\circ}$ 170/2015; PL n. ${ }^{\circ}$ 6.630/2013; PL n. ${ }^{\circ}$ 6831/2013; PL n. ${ }^{\circ} 7377 / 2014$ e PL n. ${ }^{\circ}$ 6713/2013. Todos, atualmente, apensados ao primeiro, de 9 de maio de 2013, pelo Deputado João Arruda, do PMDB/PR, visando alterar a Lei 11.340/2006 (a Lei Maria da Penha), trazendo à luz condutas ofensivas contra a mulher no meio da Internet e em outros meios de comunicação. g-e-postam-fotos-sensuais-na-internet.html?utm_source=g1\&utm_medium=email\&utm_campaign=sharethis. Acesso em 31.10.2016. 
detalhadamente o que aconteceu, para colocar para fora o que aconteceu consigo, contribuir para o debate e apoiar outras mulheres, recebendo o apoio da família e dos amigos.

Em entrevista à CartaCapital, disse:

Diversos sites usaram minha história para reafirmar o caráter da nossa sociedade opressora. Também acredito ser importante informar outras pessoas, principalmente as mulheres muito jovens, sobre os riscos que cerceiam a liberdade, a dignidade e o bem-estar. Afinal, quem não conhece a história está fadada a repeti-la. ${ }^{15}$

Demonstrando consciência e engajamento, quando inquirida sobre o que achava da eficácia da criação de lei específica, Thamiris declarou ser necessário porém não suficiente, imprescindível seria uma transformação estrutural da sociedade, através da educação infantil, por exemplo. De 2013 para o ano corrente, campanhas sobre o tema tiveram grande respaldo e, neste cenário, o depoimento de Thamiris foi de grande ajuda, vez que é significativo para a vítima ter conhecimento de outra pessoa que passou pela mesma situação e conseguiu superá-la, o lugar de fala de quem sofreu o mesmo abuso é privilegiado para o receptor que padeceu do mesmo problema.

Caso 2: «Fran», diz respeito a Francyelle dos Santos Pires, com 19 anos à época, do Estado de Goiás, que teve imagens sexuais e números de telefone divulgados pelo seu ex-namorado, o empresário Sérgio Henrique de Almeida Alves, com 21 anos à época, também goiano. No vídeo, ela fazia um sinal de «Ok» com a mão e rapidamente surgiram inúmeras fotos e montagens na Internet de pessoas comuns e celebridades fazendo o sinal, remetendo ao caso.

Em 8 de outubro de 2014 (um ano depois da divulgação do vídeo), o rapaz teve que prestar cinco meses de serviço comunitário e saiu sorrindo após acordo, enquanto Francyelle perdeu o emprego (após afastamento), saiu da faculdade e se isolou do convívio com os amigos. A delegada Ana Elisa Gomes Martins afirmou que a jovem era amante do rapaz, que era casado e que prometeu manter o vídeo em pasta secreta, mas que o divulgou para os amigos no aplicativo whatsapp. Na fase das investigações, Sérgio negava ter enviado o vídeo e ser quem aparecia nele.

A jovem tem uma filha (de 3 anos no momento), cuja imagem apareceu na Internet. O crime foi considerado pela Polícia Civil apenas como injúria com agravante: uso de meio de comunicação, por não haver prova do crime de difamação e também não se conseguiu comprovar que o autor das imagens foi quem divulgou os vídeos.

O caso foi encerrado depois que o suspeito aceitou um acordo proposto pelo Ministério Público do Estado de Goiás (MP-GO) para prestar serviços comunitários por cinco meses. São palavras da jovem:

15 «'Me senti impotente e com nojo', diz estudante que teve fotos íntimas vazadas», CartaCapital, 29.11.2013. Disponível em http://www.cartacapital.com.br/sociedade/me-senti-impotente-ecom-nojo-diz-estudante-que-teve-fotos-intimas-vazadas-3974.html. Acesso em 31.10.2016. 
[Sensação de] impunidade, porque cinco meses de pena para ajudar as pessoas não vai pagar o que ele me fez. Eu não me conformo. Ele saiu rindo da minha cara, disse que não é ele. Eu estou com muita raiva, sentida mesmo com essa situação toda, afirmou chorando.

$[\ldots]$

A vida dele continua normal. Quem sofreu as consequências fui eu. Eu quero que o meu caso sirva de lição para outras meninas que passem pelo que eu passei. Eu fui bastante forte em lidar com essa situação, mas várias meninas não.

[...]

Era com uma pessoa que eu amava e em quem eu confiava. ${ }^{16}$

As falas da jovem refletem a impossibilidade dela dispor do corpo como gostaria ou, ainda, como o parceiro do sexo masculino poderia fazê-lo. Levando-se em consideração a frequência que o fenômeno tem ocorrido contra mulheres e as consequências que tem acarretado, não há dúvidas que consiste em mais uma forma da violência de gênero, demonstrando também o ranço patriarcal que resiste na sociedade na condescendência que muitas vezes ocorre com o homem que provocou o ato.

Tal fenômeno se relaciona com a exposição exacerbada de imagens pessoais na cibercultura e com a ideia de libertação sexual que é pregada em contextos e momentos específicos, mas que majoritariamente demonstra novas formas de adequação e de padrões.

Até agora, aplicam-se nos casos os demais Códigos, geralmente o Código Penal Brasileiro (1940) e o Estatuto da Criança e do Adolescente (1990) quando se trata de menores. Quem divulga fotos e vídeos de teor sexual na rede, pode responder por ameaça, difamação, injúria, violência psicológica, violência moral, afetando os direitos à privacidade, direito à honra. Pode ocorrer também a punição do provedor da Internet, que, mesmo notificado de que o teor das imagens é criminoso e deve ser retirado do ar, mantém a divulgação.

\section{Conclusão}

Os tempos se transformam, mas também as relações e as mentalidades, o que requer reflexão e leitura crítica sobre construções e representações das mulheres nas atuais mudanças sociais cada vez mais latentes. Mais empoderadas, passíveis de inserção no sistema de reprodução e consumo, a conscientização do vivido e a compreensão dos fenômenos que constituem a universalidade abstrata da forma mercadoria são condições fundamentais para a construção do devir para além de qualquer forma/representação de poder (despótico ou patriarcal incluídos). A

16 «Suspeito de divulgar vídeo de sexo faz acordo na Justiça, em Goiânia», Globo.com, 8.10.204. Disponível em http://g1.globo.com/goias/noticia/2014/10/suspeito-de-divulgar-video-de-sexofaz-acordo-na-justica-em-goiania.html. Acesso em 16.02.2017. 
consciência crítica do que querem vivenciar coaduna-se com o entendimento de que a liberdade é a razão de ser da política (Arendt 2006). Entretanto, no compasso das mudanças, surgem desafios e ondas reacionárias, em novas linguagens e também - o que é gritante - em tradicionalismos e conservadorismos que se afiguram de forma visceral aquando da ocorrência de casos de grande comoção.

Por isso, a exigência em escovar a história a contrapelo, contrapor a cultura patriarcal, ainda vigente, e estabelecer como prioridade a emancipação, não no sentido e apelo mediático de corpos vazios e nulos, torna-se uma condição decisiva para realizar (teoria e práxis) a emancipação do sexo no capitalismo e, principalmente, apreender que o valor e dissociação estão em contínua reciprocidade dialética (Scholz 2010).

O papel da Internet, no contexto de uma conglomeração e denúncia de abusos e violências, é fundamental, desde que, como meio de divulgação/contestação, não esteja submetido à lógica do valor. Isto porque, no plano cultura-simbólico, já asseverava Scholz (2010), a linguagem e o discurso não substituem a totalidade sem o referendar crítico do plano sociopsicológico. A desconstrução da relação espaço-tempo sob a égide do capital é o primeiro passo. A conjunção das esferas econômica e política, a compreensão da liberdade como antagônica à vontade de poder, o meio para criação do sujeito ético-moral em seus distintos matizes de gênero.

As preocupações feministas estão dentro da tecnologia, não são um simples verniz retórico. Estamos falando de coabitação: entre diferentes ciências e diferentes formas de cultura, entre organismos e máquinas. Penso que as questões que realmente importam (quem vive quem morre e a que preço) - essas questões políticas - estão corporificadas na tecnocultura. Elas não podem ser resolvidas de nenhuma outra maneira (Haraway 2009, 28).

Há que se aproveitar, em um momento em que o óbvio vem à tona, para se abordar o machismo, para se exigir respeito e igualdade, o olhar sobre a mulher como sujeito de direitos, de emoções, desejos e sexualidades - em suas próprias construções identitárias, não as condicionadas pelos moldes de uma sociedade patriarcal e misógina, nem pelo prazer de outrem.

Isto sem olvidar que o aparato jurídico, com a ausência de leis específicas para a violência contra a mulher na Internet (o que entendemos como uma das esferas da ética), apenas serve ao recrudescer de distintas formas de «violências sobrepostas» (Cavalcanti e Gomes 2015). Afinal, no quadro da modernidade, em que aqueles que estão inseridos no sistema de reprodução recebem o selo de seres humanos, a solvência não garante a condição de sujeito ético-moral. Ao contrário, legitima a política da propriedade privada, da dominação dos meios e fatores de produção, dos corpos em sua forma virtualizada. Sem o reconhecimento do caráter único e negativo da riqueza abstrata, a emancipação será suplantada pelo fetichismo em todas as formas, do simulacro ao universal. 


\section{Referências bibliográficas}

Arendt, Hannah. 2006. Sobre la violencia. Madrid: Alianza Editorial.

Bauman, Zygmunt. 2008. Vida Para Consumo: a transformação das pessoas em mercadoria. Rio de Janeiro: Zahar.

Bauman, Zygmunt. 2014. Amor Líquido: sobre a fragilidade dos laços humanos. Rio de Janeiro: Zahar.

Castels, Manuel. 2003. A sociedade em rede. São Paulo: Paz e Terra.

Cavalcanti, Vanessa Ribeiro Simon, e Antonio Carlos da Silva. 2011. «Crise Global: Reflexões sobre a Sociedade do Espetáculo ao Ritmo do Capital». Portuguese Studies Review,18 (2): 129-151.

Cavalcanti, Vanessa Ribeiro Simon, e Gina Emília Gomes. 2015. «Violência(s) portas adentro: categorias relacionais como gênero e famílias em foco interdisciplinar». Pp. 313-338 in Familia no Brasil: Recurso para a pessoa e para a sociedade, organizado por Ana Cecília de Sousa Bastos, Lúcia Vaz de Campos Moreira, Giancarlo Petrini e Miriã Alves Ramos de Alcântara. Curitiba: Juruá.

Debord, Guy. 1997. A sociedade do Espetáculo. Rio de Janeiro: Contraponto.

Dornelles, Jonatas. 2004. «Antropologia e Internet: quando o campo é a cidade e o computador é a rede». Horizontes Antropológicos 21, 241-271. Disponível em http://www.scielo. br/pdf/ha/v10n21/20627.pdf. [Consultado em 3.6.2016].

Evans, Claire L. 2014. 'We Are the Future Cunt': CyberFeminism in the 90s. Disponível em http://motherboard.vice.com/read/we-are-the-future-cunt-cyberfeminism-in-the-90s. [Consultado em 14.11.2016].

Giddens, Anthony. 1993. A Transformação da Intimidade: sexualidade, amor e erotismo nas sociedades modernas. São Paulo: Editora da Universidade Estadual Paulista.

Haraway, Donna J. 2009. «Manifesto Ciborgue. Ciência, tecnologia e feminismo-socialista no final do século XX». Pp. 33-118 in Antropologia do Ciborgue: As vertigens do pós-humano. 2. ${ }^{\text {a }}$ ed. Organizado por Donna Haraway, Hari Kunzru e Tomaz Tadeu. Belo Horizonte: Autêntica.

Kurz, Robert. 2011. «Não há Leviatã que vos salve. Teses para uma teoria crítica do Estado». EXIT! Crise e Crítica da Sociedade da Mercadoria 7. Tradução de Boaventura Antunes e Lumir Nahodil. Disponível em http://www.obeco-online.org/rkurz390.htm. [Consultado em 18.4.2017].

Lemos, Marina Gazire. 2009. Ciberfeminismo: Novos discursos do feminino em redes eletrônicas. Dissertação de Mestrado em Comunicação e Semiótica, Pontíficia Universidade Católica de São Paulo.

Leonardi, Marcel. 2011. Tutela e Privacidade na Internet. São Paulo: Saraiva. Disponível em http://leonardi.adv.br/wp-content/uploads/2012/01/mltpi.pdf. [Consultado em 16.2.2017].

Lévy, Pierre. 2009. Cibercultura. São Paulo: Editora 34.

Lipovetsky, Gilles. 2005. A Era do Vazio. Barueri, SP: Manole.

Natansohn, Graciela (org.). 2013. Internet en código femenino: Teorias y práticas. Buenos Aires: La Crujía.

Plou, Dafne Sabanes. 2013. «Novos cenários, velhas práticas de dominação: a violência contra as mulheres na era digital». Pp. 121-136 in Internet em Código Feminino. Teorias e Práticas, organizado por Graciela Natansohn. Buenos Aires: La Crujía.

Santos, Simone Ganem dos. 2014. Mapeando os Corpos Femininos na História do Tempo Presente: diálogos e representações. Tese de Doutorado em Família na sociedade contemporânea, Universidade Católica do Salvador, Salvador. 
Saffioti, Heleiete. 2004. Gênero, Patriarcado, Violência. São Paulo: Fundação Perseu Abramo. Scholz, Roswitha. 2010. «Forma social e totalidade concreta. Na urgência de um realismo dialético hoje». EXIT! Crise e Crítica da Sociedade da Mercadoria 6. Tradução de Boaventura Antunes e Virgínia Saavedra. Disponível em http://www.obeco-online.org/ roswitha_scholz12.htm [Consultado em 18.4.2017].

Sibilia, Paula. 2008. La Intimidad como Espetáculo. Buenos Aires: Fondo de Cultura Económica de Argentina.

Mariana Risério Chaves de Menezes. Mestranda em Família na Sociedade Contemporânea, Universidade Católica do Salvador (UCSAL), integrante do Núcleo de Estudos sobre Direitos Humanos (NEDH/UCSAL/CNPq). Bolsista da Fundação de Amparo à Pesquisa do Estado da Bahia (FAPESB) e com intercâmbio na Universidade Portucalense (Portugal) em 2015.

Vanessa Ribeiro Simon Cavalcanti. Pós-doutorada em Direitos Humanos pela Universidade de Salamanca e doutora em Humanidades pela Universidade de Leon (Espanha). Docente investigadora dos Programas de pós-graduação em Família na Sociedade Contemporânea da Universidade Católica do Salvador (PPGFSC/UCSAL) e em Estudos Interdisciplinares sobre Mulheres, Gênero e Feminismo (PPGNEIM/ UFBA), Brasil. Integrante do Núcleo de Estudos sobre Direitos Humanos (NEDH/ UCSAL) e do Instituto de Sociologia da Universidade do Porto (IS/UPORTO).

Artigo recebido em 30 de dezembro de 2016 e aceite para publicação a 07 de fevereiro de 2017. 